\author{
F. M. Raimondo, D. Varshanidze \& E. Di Gristina
}

\title{
The class Scheuchzerio-Caricetea nigrae in Sicily: a new association of the Caricion nigrae from the Madonie Mountains
}

\begin{abstract}
Raimondo, F. M., Varshanidze, D. \& Di Gristina, E.: The class Scheuchzerio-Caricetea nigrae in Sicily: a new association of the Caricion nigrae from the Madonie Mountains. - Bocconea 29: 279295. 2021 - ISSN: 1120-4060 printed, 2280-3882 online.

The presence of hygrophilous vegetation aspects related to the Scheuchzerio-Caricetea nigrae class is analyzed and reported in Sicily, on the Madonie Mountains. It is represented today by a single association which in the same mountains has had greater extension in the past. Despite the damage and severe reductions suffered in the last decades of the last century, the small Sicilian peaty stations still survive in the only locality of Scorzone locality, in the territory of Geraci Siculo (Palermo) and host phytocoenoses that are unprecedented from a phytosociological point of view. In the case of Scorzone area, it is an unprecedented association that is established and described here with the name of Sphagno auriculati-Caricetum echinatae. Its floristic composition and both biological and biogeographic structure are analyzed. Its syntaxonomic classification is also proposed within the Caricion nigrae alliance (Caricetalia nigrae), sintaxon so far also indicated in the southern Apennines, up to Calabria, on the Aspromonte. The new association has an affinity with the Sphagno inundati-Caricetum stellulatae from the extreme region of Italian Peninsula. Sphagno auriculati-Caricetum echinatae, however, differs from the continental one for the greater floristic richness. Given the precariousness of the biotope, the study takes into consideration its state of conservation and the looming dangers that the described association runs, which for the European territory marks the extreme southern limit of the Scheuchzerio-Caricetea nigrae class.
\end{abstract}

Key words: Vegetation, Sphagno auriculati-Caricetum echinatae, Caricetalia nigrae, Madonie Mountains, Mediterranean islands.

\section{Introduction}

The Scheuchzerio palustris-Caricetea nigrae class includes all associations linked to large and small peat bogs in Europe. The latter in Italy are widespread from the Alps to the most extreme Apennine regions. Since these are environments in which the bryophytes in particular the species of the genus Sphagnum - help to define and characterize its phytocoenoses, it is natural that they are found in the areas and environments in which these particular bryophytes can be planted and found. 
In the Italian territory, the cited class is present with dozens of associations mainly located in the Alps and in the Apennines up to Calabria (Biondi \& al. 2014). In this extreme peninsular region, their placement took place recently for Aspromonte area (Brullo \& al. 2001).

In Sicily, not the genus Sphagnum but the small sphagnum peat bogs were reported for the first time in the Madonie Mountains by Raimondo \& Dia (1978). The same authors reported various taxa of the aforementioned genus to Sicily, then progressively reunited in only three species: Sphagnum auriculatum Schimp., S. contortum Schultz, and $S$. subsecundum Nees (Aleffi \& al. 2020).

In the central and largest island of the Mediterranean, the genus Sphagnum is found at the extreme southern limit of the European range. Its presence in Sicily was and remains very localized: the Madonie Mountains, as well as for other boreal species, constitute its only seat.

The residual and only Sicilian sphagnum peat bogs stations, in the above-mentioned mountains, are mainly located in the territory of Petralia Sottana, Petralia Soprana and Geraci Siculo (Fig. 1) (Raimondo \& Romano 1984). They are located in a small area which, due to climatic, geo-pedological and vegetational affinities, can be considered the most extreme offshoot of the Apennines. Mount Catarineci (1660 m a.s.1.) (Fig. 2), located in the easternmost part of the mountain system (Fig. 3), in its northern slopes was rich in the most beautiful expressions of sphagnum peat bogs, almost all destroyed in the years 1974-1980 for the capture of small springs of mineral waters for commercial purposes. The aforementioned study by Raimondo \& Dia (1987) listed and localized as many as 26 (Fig. 4). Today the situation has considerably regressed and only two stations can be confirmed with respect to those previously ascertained (Fig. 4).

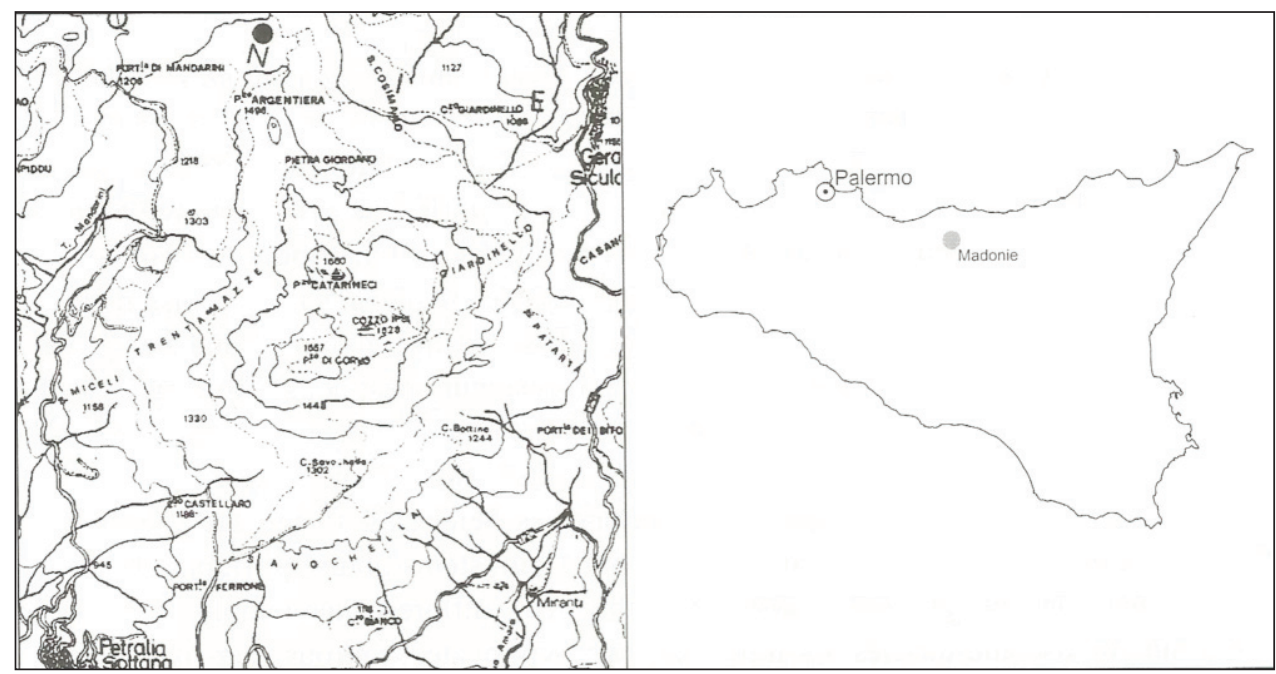

Fig. 1. Location in Sicily of the studied area in the Madonie Mountains. 
The same study reported for the Madonie Mountains as many as 6 species of the genus Sphagnum: the mentioned $S$. auriculatum, S. contortum, S. subsecundum, but also $S$. obesum (Wilson) Warnst. (= S. inundatum Russow), S. rufescens (Nees \& Hornsch.) Warnst., and $S$. magellanicum Brid. subsequently recognized as $S$. contortum and $S$. subsecundum.

In the same years, several species of Carex L. new to the Sicilian flora were also reported in these same small peat bogs: C. paniculata L., C. pallescens L. (Marcenò \& Raimondo 1977), Carex $\times$ boenninghausiana Weihe (Raimondo 1979), C. demissa Hornem. (Raimondo 1980) and C. laevigata Sm. (Raimondo \& Ottonello 1981). Later, C. stellulata L. (= C. echinata Murray) was still reported in the locality Scorzone, the only small sphagnum peat bog that remained partially free from systematic water catchments (Raimondo \& Spadaro, 2002). In this limited environment, the plant community in which C. stellulata occurred (Fig. 3) was almost dominated by Sphagnum auriculatum. Following this discovery, the first phytosociological surveys were made which subsequently allowed their elaboration. The result was an unprecedented plant community for the vegetation of the Sicilian mountains. In this contribution, it is today analyzed and typified phytosociologically. The result is a new association proposed with the name Sphagno auriculati-Caricetum echinatae. From a syntaxonomic point of view it is framed in the Scheuzerio-Caricetea nigrae class which, thus, is also represented on the island of Sicily, in the heart of the Mediterranean Basin.

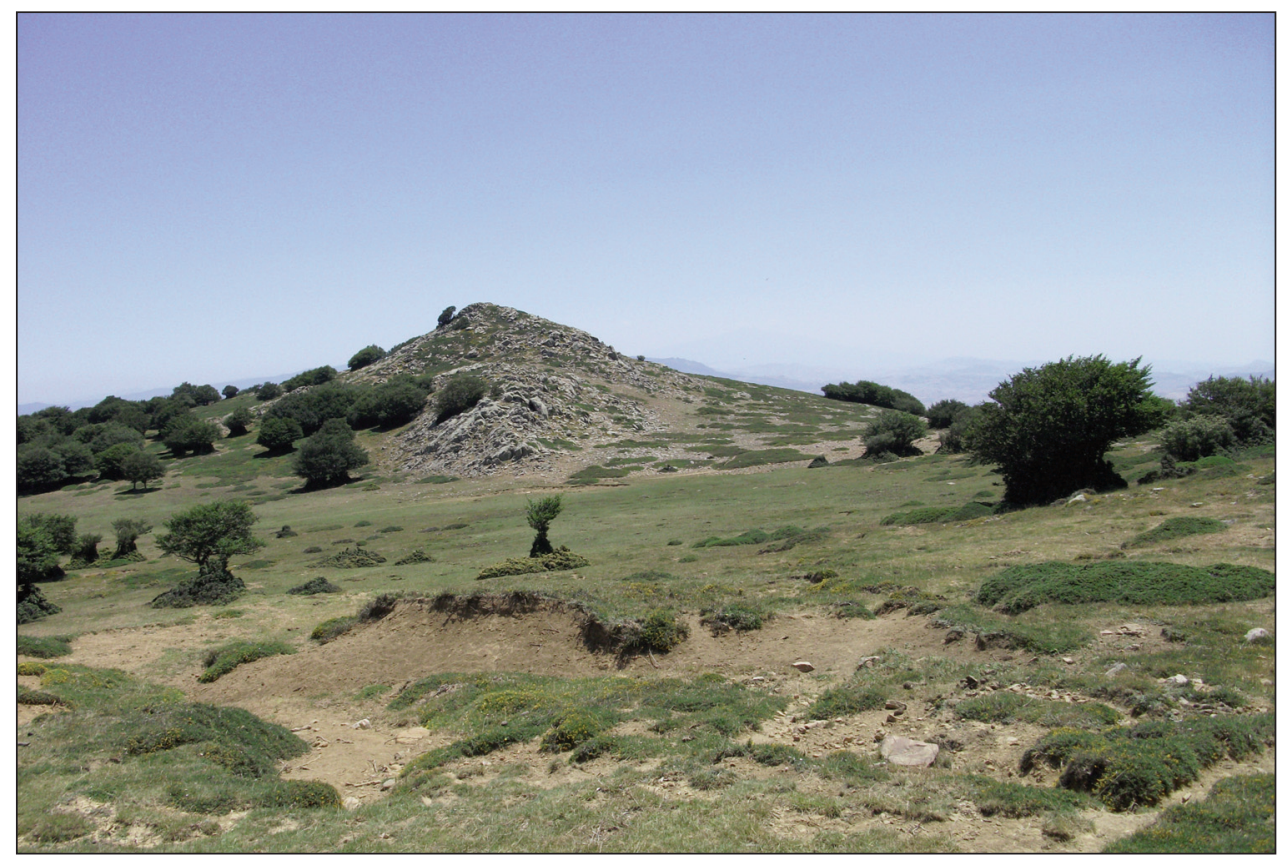

Fig. 2. The quartzarenite relief of Monte Catarineci (1660 m a.s.1.) located in the eastern sector of the Madonie Mountains, in contact with the Nebrodi Mountains. 
282 Raimondo \& al.: The class Scheuchzerio-Caricetea nigrae in Sicily: a new association...

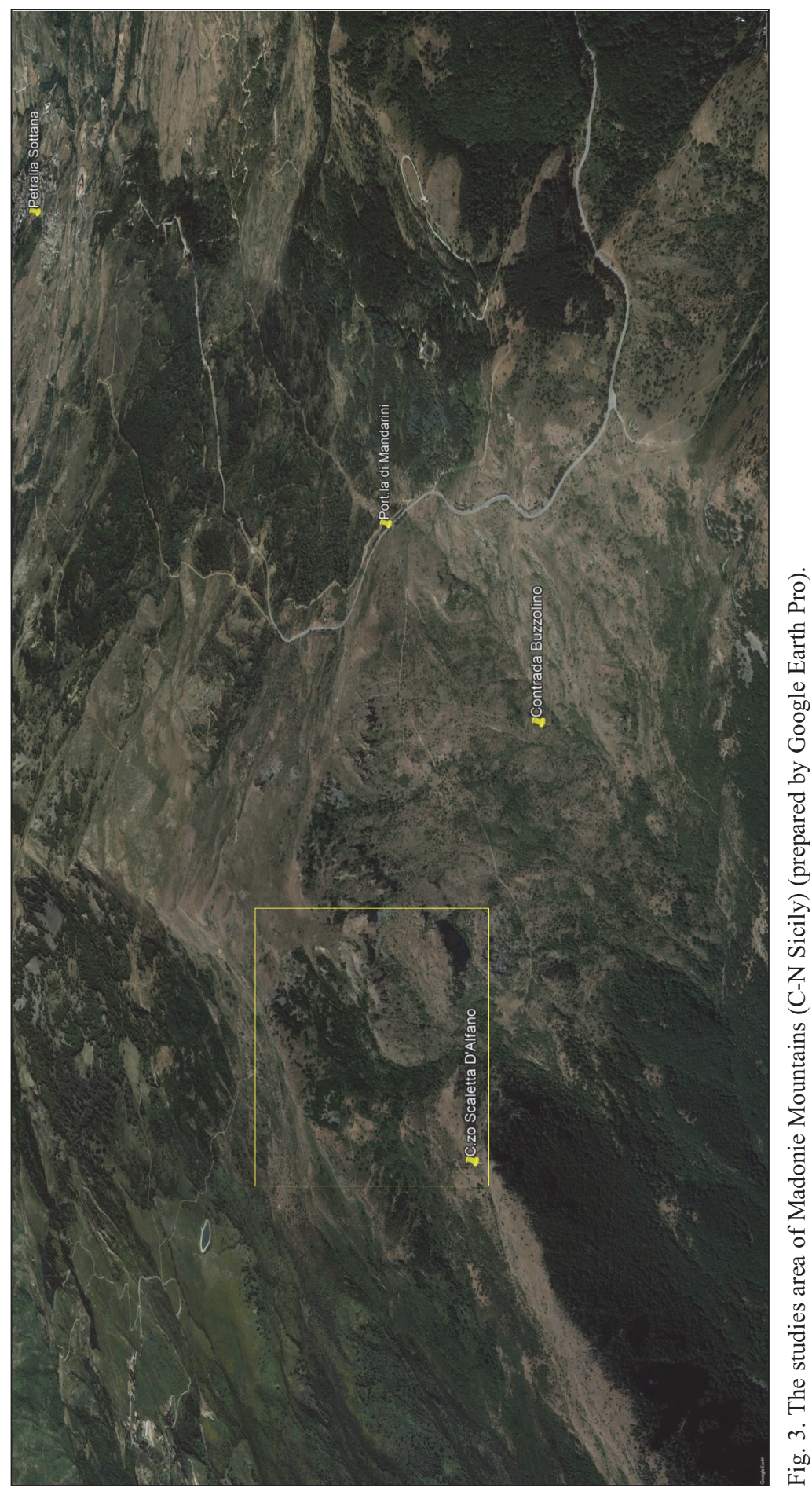




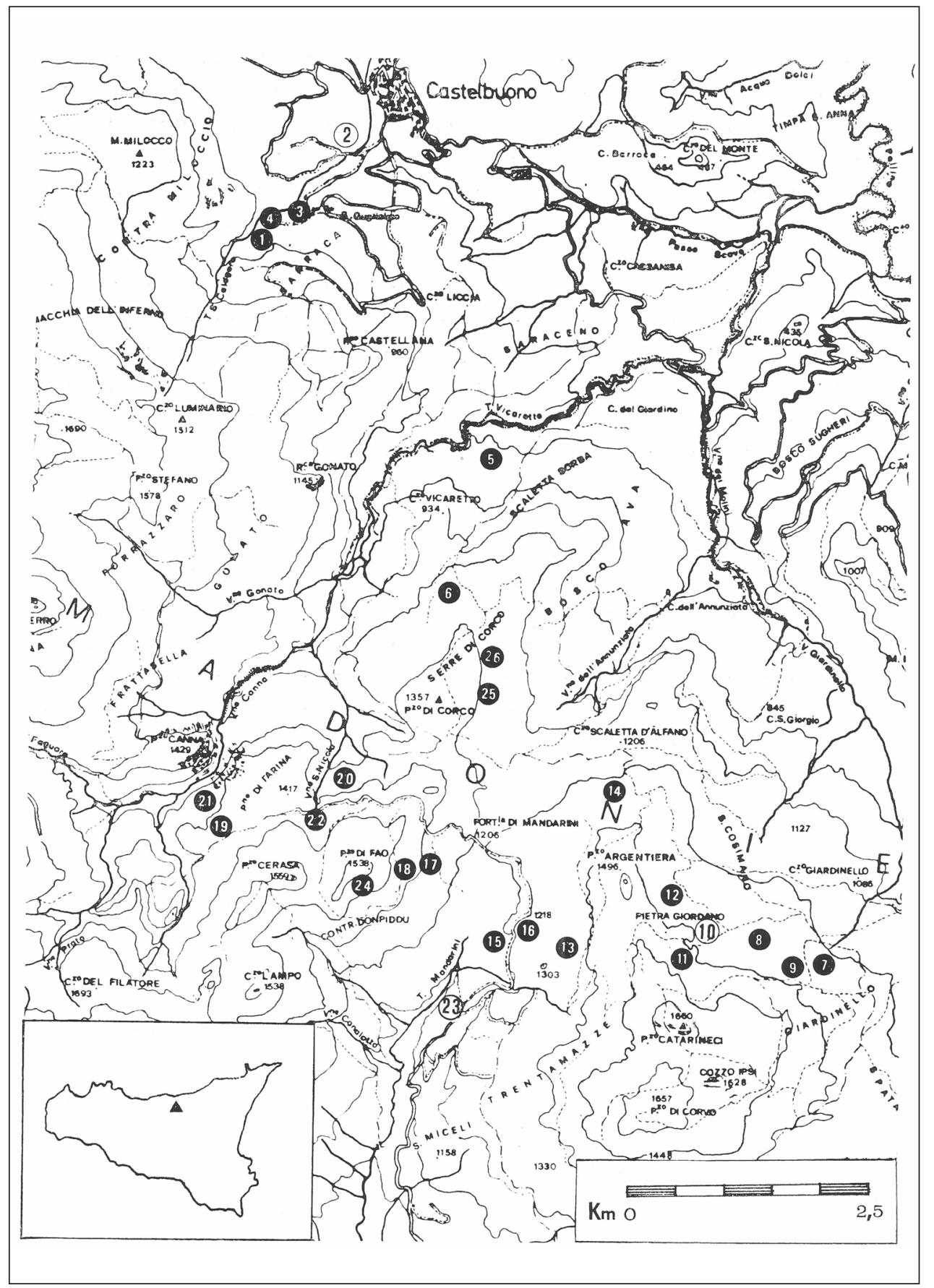

Fig. 4. Distribution of the small sphagnum peat bogs in Sicily (Madonie Mountains) surveyed by Raimondo \& Dia (1978). 


\section{Ecological and phytocenotic characteristics of peaty sphagnum stations ascertained in Sicily}

As mentioned, the small sphagnum peat bogs in Sicily are located exclusively on the Madonie Mountains. Censored by Raimondo \& Dia (1978), they have been referred to a special habitat: the so-called - as defined by Petronici \& al. (1978) "Triemule a briofite acidofile" (trempling bog with acidophilic bryophytes). It was characterized by some chemical characteristics of peat; in particular for the rather low $\mathrm{pH}$ (in some stations 3.05), and organic carbon values around 35\%; total limestone was absent.

The sphagnum peat bogs under examination had their main seat within the relict holly vegetation belt, in the potential area of mixed submontane woods (Quercetalia pubescenti-petraeae Klika 1933) (see Di Martino \& al. 1977; Raimondo 1984) where they were often imprisoned. In the wetter valleys they descended to about 700-600 meters, in the full Mediterranean horizon, in the potential area of Mediterranean woods (Quercetalia ilicis Br.-B1. 1936).

Especially in these thermophilic stations, colonies of Sphagnum rufescens s. 1. and $S$. auriculatum alternate with luxuriant groupings with Osmunda regalis, L., Athyrium filix-femina (L.) Roth, Blechnum spicant (L.) Roth, Juncus effusus L., J. articulatus L. s.1., Carex remota L., Eupatorium cannabinum L., Holcus lanatus L., etc. The plant community physiognomized by Osmunda regalis is believed to have characterized the most evolved phase of the wet aspect of the sphagnum peat bogs. The more mesophilic stations were less rich in this fern and other pteridophytes, although some species were found there almost constantly. They passed through Cyperaceae, Juncaceae and Poaceae formations, towards the remains of the IliciQuercetum austrotyrrhrenicae which, like a circular vise, narrowed with a centripetal trend, as the peat freed itself from the aquifer.

Sphagnum obesum ( $=S$. inundatum), often constituted submerged monospecific aspects. Carex demissa Hornem. and Utricularia australis R. Br. were found, respectively, at the points of emergence or in the small depressions. Mentha aquatica L., Dactylorhiza saccifera L. and Juncus articulatus L. s.l., find each other with difficulty but with constancy. Furthermore, S. contortum and Sphagnum rufescens were the species that often mixed with Aulacomnium palustre (Hedw.) Schwaegr., another very interesting moss of these acidophilic environments, on which a specific phytogeographic survey was conducted (Raimondo \& al. 1984).

Among the sphagnum peat bogs of the stations of the Madonie Mountains liverworts have been found such as Calypogeia trichomanis (L.) Corda, C. fissa (L.) Corda, C. arguta Nees \& Mont., Lophocolea bidentata (L.) Dum., Bazzania trilobata (L.) Gray and, among the other mosses, Polytrichum commune Hedw., often in developed autonomous consortia linked more to the less hygrophilous phytocenosis dominated by Osmunda regalis (see Raimondo \& al. 1981). Pellia epiphylla (L.) Corda, among the thalose liverworts, often settled on Sphagnum rufescens, while the more open spaces were colonized by Solenostoma crenulatum (Sm.) Mitt. On the soaked sphagnum some macrophytes were found including Solenopsis minuta subsp. nobilis (F. E. Wimm.) Meikle, Bellis hybrida Ten., Ranunculus fontanus C. Presl, Samolus 
valerandi L., Carex punctata Gaudin, Lysimachia nemorum L., Hypericum tetrapterum Fries and Dactylorhiza saccifera L.

The phytosociological classification of these mentioned aspects of vegetation constituted a considerable problem which was partly addressed many years later.

\section{Materials and methods}

The investigation area is limited to the eastern part of the Madonie Mountains. It is located almost entirely within the territory of Geraci Siculo. (Fig.1). Meaningful relief in this sector are Monte Catarineci (1660 m a.s.1.) (Fig. 2). The vegetation examined was that of the small streams in the southern slopes of the cited Monte Catarineci (Figs. 3, 5), space occupied by deciduous oaks with dominance of Ilex aquifolium L. (Quercion pubescentis-petraeae) (Fig. 6a) below and thermophilous beech forests (Geranio versicoloris-Fagion) (Fig. 6b). The vegetation survey was carried out in summer (august), following the phytosociological method of the Zurich-Monpellier school. The individual surveys have been brought together in Table 1.

In our contribution, in presence of the updated summaries by Biondi \& al. (2014) for the vegetation of Italy, rather the latest synthesis on a European scale, proposed by Mucina \& al. (2016), we preferred referring to the first authors, considering it more responsive to the Sicilian vegetation. Therefore, the phytosociological classification of the vegetation analyzed here, is referred to the syntaxa units recognized by Biondi \& al. (2014) which are also followed for the nomenclature of the mentioned syntaxa in the text and Annex $a$. The nomenclature of the plants cited in text, captions, tables, and Annex $b$ follows Bartolucci \& al. (2018), except a few cases. Furthermore, both for biological categories and for chorological types, reference is made to Raimondo \& al. (2010). The reunion in six contingents of the numerous chorological types, represented in the detected florulae, follows Di Martino \& Raimondo (1979). The calculation of the qualitative (florula) and quantitative (vegetation) weight of the biological and chorological types is based on the work of Di Martino \& Raimondo (1976).

\section{Results and discussion}

The analysis of the data in Table 1 allows us to frame the examined vegetation in a new association called Sphagno auriculati-Caricetum echinatae. It is presented and described below

Sphagno auriculati-Caricetum echinatae Raimondo \& Di Gristina ass. nov. hoc loco (Table 1)

Type: Rel. 2 in Table 1 (geographic coordinates: $37^{\circ} 51^{\prime} 58.171^{\prime \prime N} / 14^{\circ} 07^{\prime} 01.64 " \mathrm{E}$ ). 
Table 1. Sphagno auriculati-Caricetum echinatae ass. nov. hoc loco (Caricion nigrae, Caricetalia nigrae, Scheuchzerio-Caricetea nigrae)

\begin{tabular}{|c|c|c|c|c|c|c|c|c|c|}
\hline Biological form & Chorological type & Relevé $\left(n^{\circ}\right)$ & 1 & 2 & 3 & 4 & 5 & \multirow{8}{*}{ 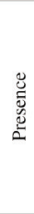 } & \multirow{8}{*}{ 党 } \\
\hline & & Altitude ( $\mathrm{m}$ a.s.l.) & 1215 & 1220 & 1225 & 1231 & 1228 & & \\
\hline & & Exposure & N-W & N-W & N-W & $\mathrm{N}-\mathrm{W}$ & $\mathrm{N}-\mathrm{W}$ & & \\
\hline & & Slope $\left(^{\circ}\right)$ & 10 & 12 & 12 & 14 & 12 & & \\
\hline & & Total cover $(\%)$ & 100 & 100 & 100 & 100 & 100 & & \\
\hline & & Everage height $(\mathrm{cm})$ & 25 & 30 & 30 & 35 & 30 & & \\
\hline & & Area $\left(m^{2}\right)$ & 9 & 9 & 9 & 9 & 9 & & \\
\hline & & Species per elevé $\left(n^{\circ}\right)$ & 26 & 20 & 15 & 25 & 13 & & \\
\hline & & Char. Association & & & & & & & \\
\hline H caesp & Euroamer. (Anfiatl.) & Carex echinata & 2.3 & 3.4 & 2.3 & 3.4 & 3.4 & 5 & V \\
\hline Tall & Boreale & Sphagnum auriculatum & 4.4 & 4.5 & 4.4 & 3.4 & 4.4 & 5 & $\mathrm{v}$ \\
\hline H caesp & NE-Medit.-Mont. & Ranunculus fontanus & +.2 & 1.2 & +.2 & . & +.2 & 4 & IV \\
\hline \multirow[t]{2}{*}{ T scap } & W-Stenomedit. & Solenopsis bivonae & +.2 & +.2 & . & +.2 & . & 3 & III \\
\hline & & Char. alleance, order and class & & & & & & & \\
\hline H caesp & Euroamer. (Anfiatl.) & Carex demissa & +.2 & 1.2 & 1.2 & 1.2 & 1.2 & 5 & $\mathrm{~V}$ \\
\hline H caesp & Eurimedit.-Subatl. & Carex punctata & & +.2 & +.2 & +.2 & +.2 & 4 & IV \\
\hline Tall & Boreal & Aulacomnium palustre & 1.2 & 1.2 & . & +.2 & . & 3 & III \\
\hline \multirow[t]{2}{*}{ Tall } & Subboreal & Polytrichum commune & +.2 & +.2 & . & . & . & 2 & II \\
\hline & & Other taxa & & & & & & & \\
\hline H rept & Paleotemp. & Trifolium repens & +.2 & 1.2 & . & +.2 & . & 3 & III \\
\hline T scap & Subtrop. & Isolepis setacea & +.2 & +.2 & . & - & +.2 & 3 & III \\
\hline H caesp & Eurimedit. & Carex distans & +.2 & +.2 & . & . & . & 2 & II \\
\hline H caesp & Eurosib. & Juncus conglomertus & +.2 & $\cdot$ & . & +.2 & . & 2 & II \\
\hline H scap & Eurasiat. & Lysimachia nemorum & . & +.2 & + & . & + & 3 & III \\
\hline H caesp & Eurasiat. & Poa trivialis & +.2 & +.2 & . & 1.2 & + & 3 & III \\
\hline G rhiz & Paleosubtrop. & Juncus fontanesii & . & 1.2 & . & +.2 & +.2 & 3 & III \\
\hline H caesp & Cosmopol. & Samolus valerandi & . & + & +.2 & . & . & 2 & II \\
\hline H scap & Cosmopol. & Veronica anagallis-aquatica & +.2 & . & . & +.2 & . & 2 & II \\
\hline H scap & Eurimedit. & Galium palustre subsp. elongatum & $\cdot$ & +.2 & . & +.2 & . & 2 & II \\
\hline H ros & Subendemic & Bellis perennis subsp. hybrida & $\cdot$ & +.2 & . & +.2 & . & 2 & II \\
\hline $\mathrm{H}$ ros & Paleotemp. & Potentilla reptans & +.2 & . & . & +.2 & . & 2 & II \\
\hline H caesp & Eurimedit. & Festuca circummediterranea & . & . & +.2 & + & . & 2 & II \\
\hline H scap & Paleotemp. Boreal & Lycopus europaeus & . & . & +.2 & $\cdot$ & +.2 & 2 & II \\
\hline Tall & Temperate & Calliergonella cuspidate & . & . & +.2 & +.2 & . & 2 & II \\
\hline H scap & Paleotemp. & Mentha aquatica & +.2 & . & +.2 & $\cdot$ & . & 2 & II \\
\hline H scap & Paleotemp. & Hypericum tetrapterum & $\cdot$ & +.2 & $\cdot$ & +.2 & . & 2 & II \\
\hline G bulb & Stenomedit. & Dactylorhiza maculata subsp. saccifera & + & . & . & + & . & 2 & II \\
\hline$P$ caesp & Stenomedit. & Salix pedicellata & +.2 & . & . & 1.2 & . & 2 & II \\
\hline H scap & Europ.-Caucas. & Teucrium scordium & +.2 & . & +.2 & $\cdot$ & . & 2 & II \\
\hline G rhiz & Subcosmop. & Osmunda regalis & +.2 & . & $\cdot$ & +.2 & . & 2 & II \\
\hline $\mathrm{H}$ ros & Subcosmop. & Athyrium filix-foemina & +.2 & . & . & +.2 & . & 2 & II \\
\hline $\mathrm{H} \operatorname{ros}$ & Circumbor. & Struthiopteris spicant & +.2 & . & . & +.2 & . & 2 & II \\
\hline G rhiz & Cosmopol. & Pteridium aquilinum & +.2 & . & . & $\cdot$ & +.2 & 2 & II \\
\hline H scap & Paleotemp. & Eupatorium cannabinum & $\cdot$ & . & +.2 & +.2 & . & 2 & II \\
\hline H scap & Eurimedit. & Pulicaria dysenterica & +.2 & . & . & . & +.2 & 2 & II \\
\hline H scap & Eurimedit. & Mentha pulegium & +.2 & . & +.2 & . & . & 2 & II \\
\hline H caesp & Circumbor. & Holcus lanatus & . & . & +.2 & . & +.2 & 2 & II \\
\hline Tall & & Calypogeia sp. & . & +.2 & . & . & . & 1 & I \\
\hline H caesp & Subcosmop. & Deschampsia cespitosa & +.2 & . & . & . & . & 1 & I \\
\hline H caesp & Europ.-Caucas. & Carex paniculata & . & . & . & +.2 & . & 1 & I \\
\hline H rept & Eurasiat. & Veronica beccabunga & . & + & . & . & . & 1 & I \\
\hline NP & & Rubus sp. & . & . & . & + & . & 1 & I \\
\hline Tall & & Mnium sp. & +.2 & . & . & . & . & 1 & I \\
\hline
\end{tabular}




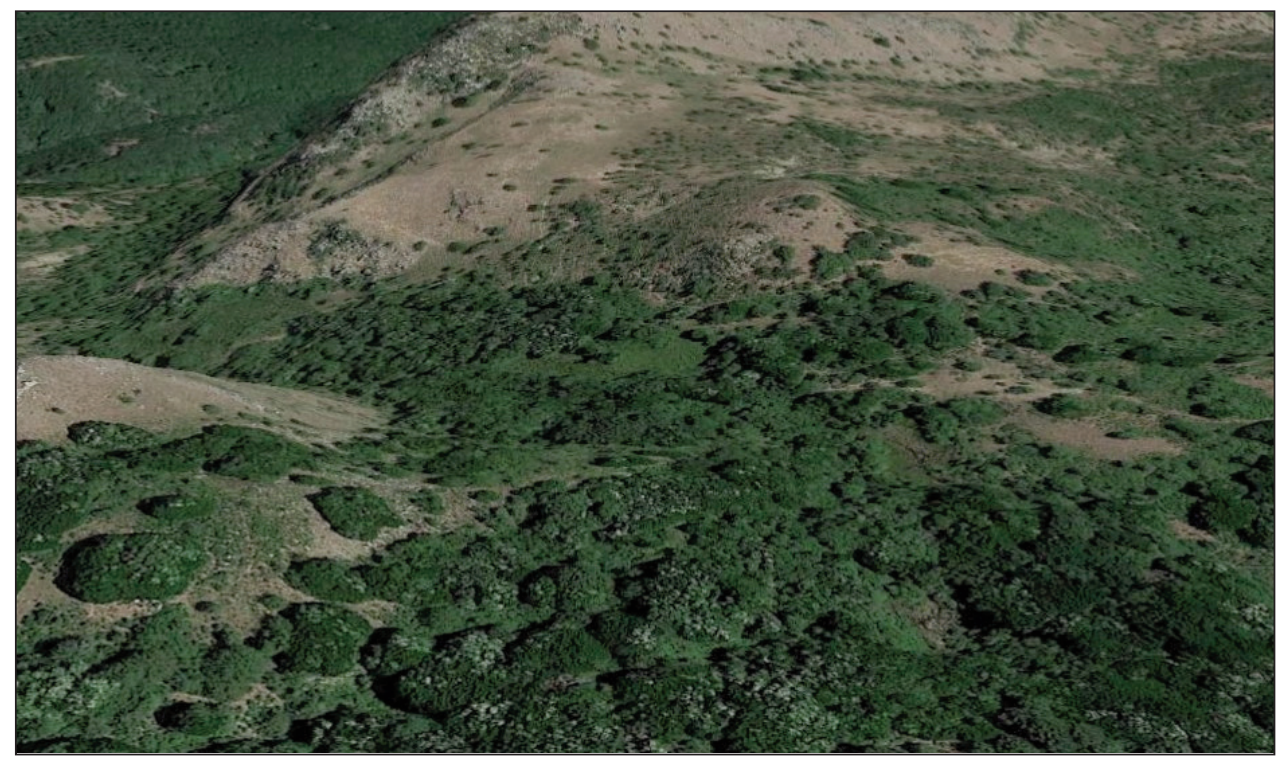

Fig. 5. View of the area where the small sphagnum bog falls on the north-western slopes of Mount Catarineci (Madonie Mountains, Sicily) (from Google Earth).

It is a hygrophilous herbaceous vegetation, essentially consisting of Carex echinata and Sphagnum auriculatum (Fig. 7).

Characteristic species - It characterizes this association the species mentioned, Carex echinata and Sphagnum auriculatum. Among the other characteristics there are Ranunculus fontanus - a Mediterranean mountain element and Solenopsis bivonae, other Mediterranean element. Theirs role in the Sicilian association is respectively local and territorial, playing roles as characteristics of other associations of different phytosociological classes in the Italian Peninsula and Sicily.

Floristic organization - The herbaceous hygrophilous vegetation investigated (Fig. 7) consists basically of two species: the bryophyte Sphagnum auriculatum and the vascular plant Carex echinata. Other bryophytes and many other vascular plants, particularly perennials, help to structure the very special and rare Sicilian mountain vegetation (see Table 1).

Biological and chorological structure - The examined association consists of species belonging to different biological categories, among which, the hemicryptophytes (66.7 and $67,4 \%$ ) and the thallophytes (14.2 and $14.3 \%$ ) (Fig. 8) stand out, both qualitatively and quantitatively. Geophytes, chamaephytes and phanerophytes, equivalent in weight, they have little influence on the structure of the proposed association (Fig. 9).

From the biogeographical point of view, the florula is represented by different chorological contingent. The boreal contingent (41and $40 \%$ ), the Mediterranean (23.1 and 20 \%) (Fig. 10), and Western contingent (7.7 and $14.7 \%$ ) play a considerable role (Fig. 11). 


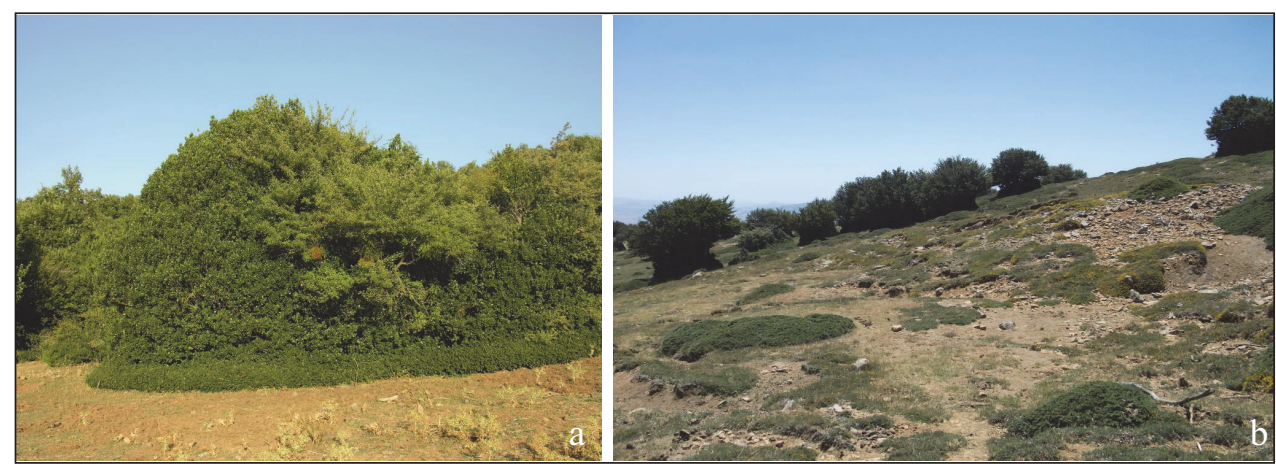

Fig. 6. Degraded aspects of the forest vegetation within which the small sphagnum peat bogs of the Madonie Mountains (Sicily) were found: a) the remains of the oak and holly wood; b) remains of the beech and holly wood.

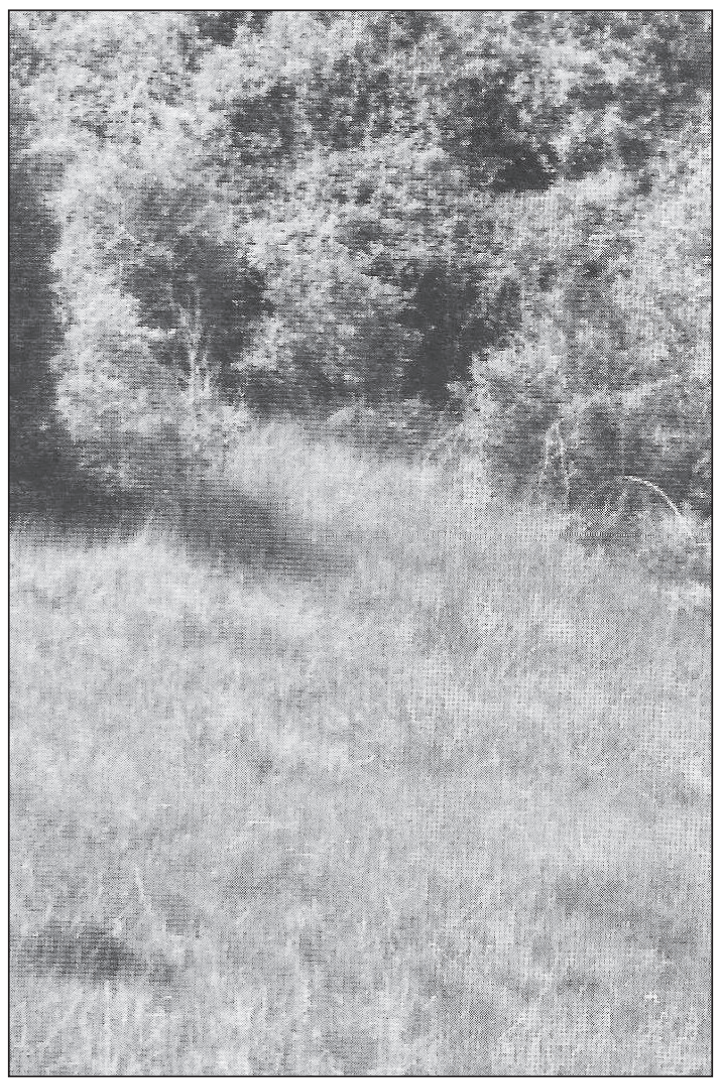

Fig. 7. Typical aspect of the new association Sphagno auriculati-Caricetum echinatae from Scorzone locality (from Raimondo \& Spadaro 2002). 


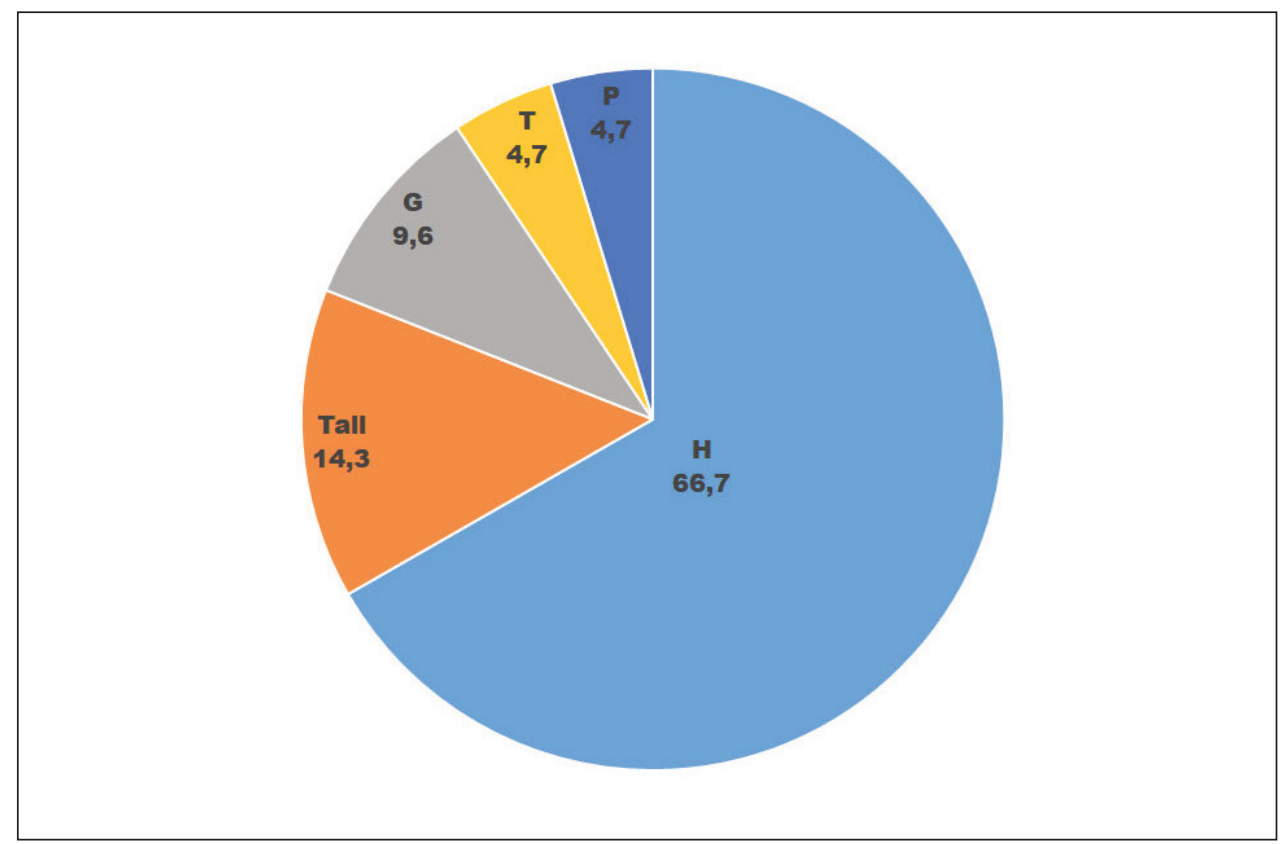

Fig. 8. Biological spectrum of the florula.

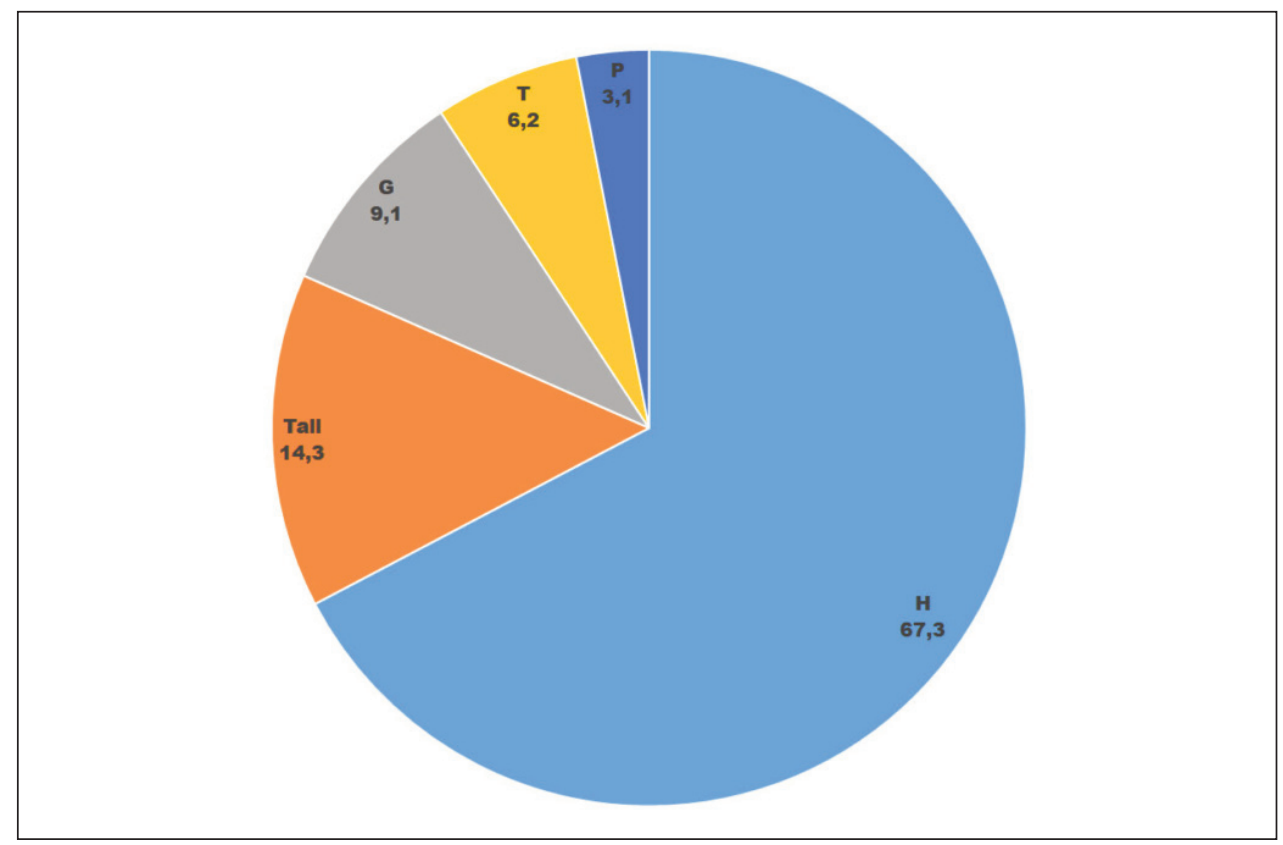

Fig. 9. Biological spectrum of the vegetation. 
There was a significant increase in the weight of this contingent, represented by 3 species, in the vegetation: from 7.7 in the flora to $14.7 \%$ in the vegetation. In the boreal contingent there are some taxa that in Sicily are found exclusively in mountain areas.

Ecology, dynamics and distribution - The vegetation examined occupies a little area surrounded by forest vegetation that has been degraded due to strong grazing (Fig. 5). It therefore tends to evolve towards grassland formations of Cynosurion cristati and subsequently towards the mixed forest of oak and holly (Quercetalia pubescenti-petraeae) falling within the relict vegetation belt of the colchic type recalled by Cambria \& Raimondo (2021).

Phytosociological framework - In the floristic frame of Table 1, the contingent of species characteristic of the class Scheuchzerio-Caricetea nigrae, and of the units subordinate to it (Caricetalia and Caricion nigrae), is well represented. In particular the mentioned syntaxa are represented by Aulacomnuin palustre, Polytrichum commune, Carex punctata and Carex demissa. For this, and for its ecological and other floristic character, the Sghagno auriculati-Caricetum echinatae association is here referred to the alliance Caricion nigrae, order Caricetalia nigrae, class Scheuchzerio palustris-Caricetea nigrae.

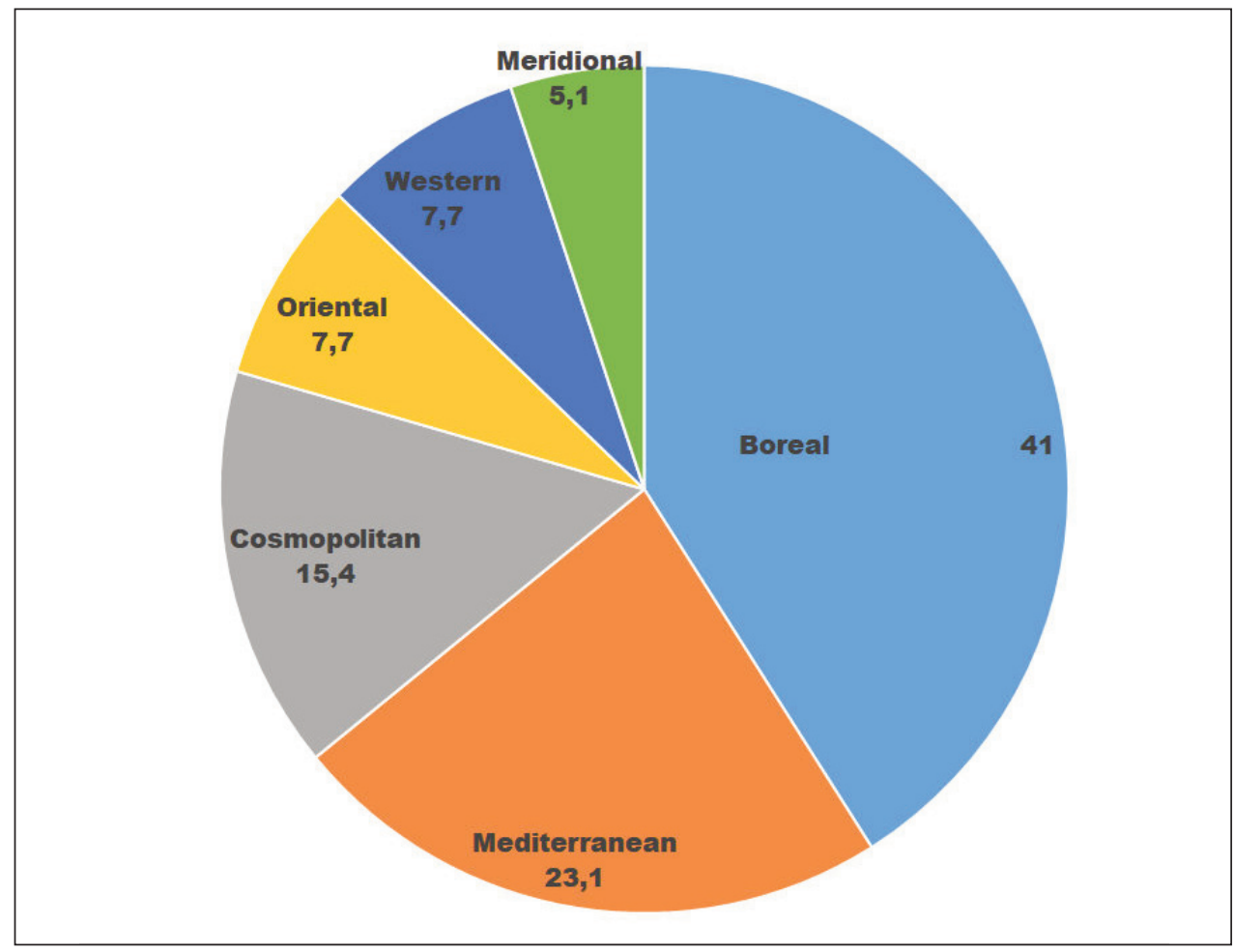

Fig. 10. Chorological spectrum of the florula. 


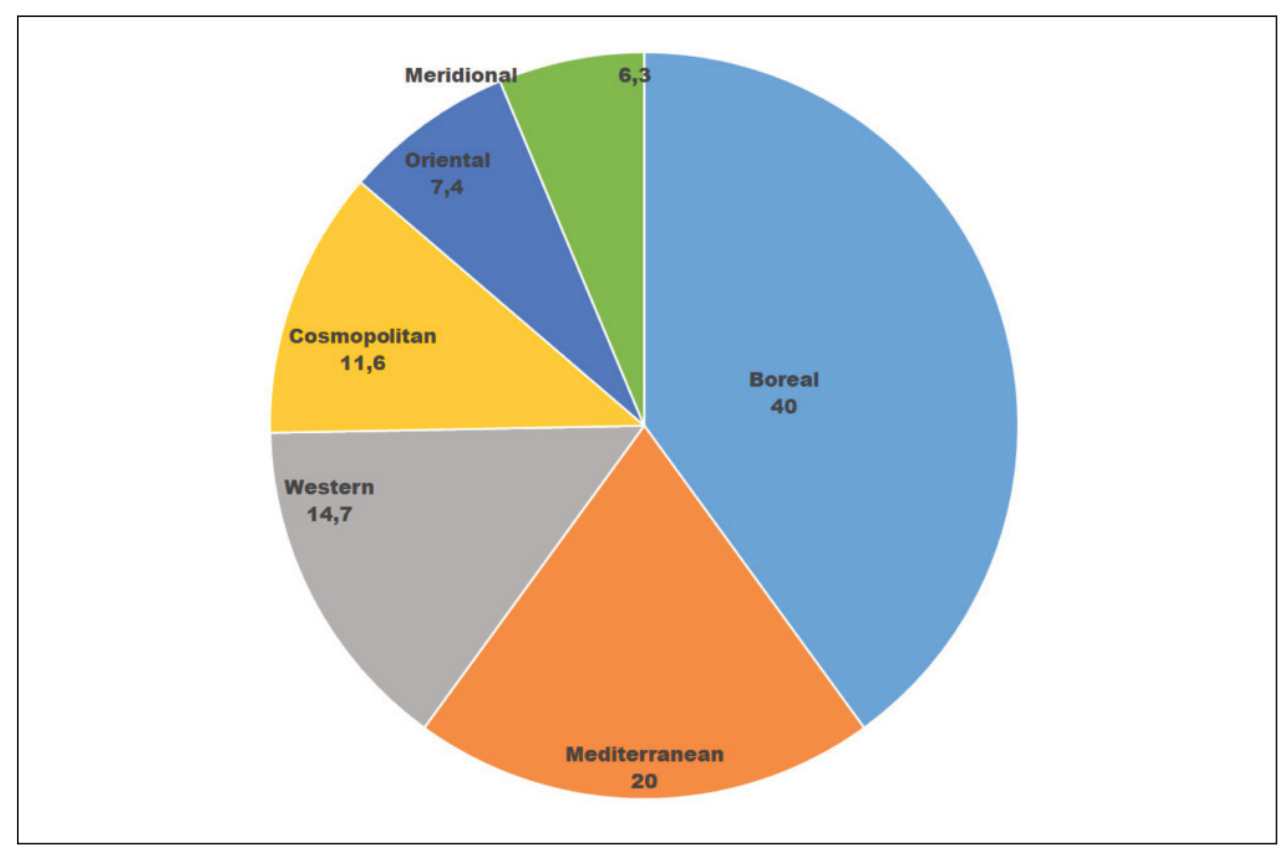

Fig. 11. Chorological spectrum of the vegetation.

\section{Conclusion}

The presence in Sicily of aspects of vegetation referable to the Parvocaricetea Westhoff in Westhoff \& Den Held 1969 [syntax. syn. of Scheuchzerio palustrisCaricetea nigrae nom. mut. propos. ex Steiner 1992; original name ScheuchzerioCaricetales fuscae Tüxen 1937] was hypothesized 40 years ago by Raimondo \& al. (1980). Since then, no studies have been developed and after years the type of environment and vegetation that was then attracted to scholars, has undergone a sharp reduction. Miraculously, one of the 26 small sphagnum peat bogs in Sicily documented by Raimondo \& Dia (1978) was spared from the works of capturing the water source, and this allowed us to be able to analyze it phytosociologically and to be able to document that in reality the mentioned class of vegetation goes south as far as Sicily, thanks to the new association described here.

Due to the presence of some characteristic species of the alliance and order Caricion and Caricetalia nigrae, it is linked to the Scheuchzerio-Caricetea nigrae class. As mentioned, this class brings together the plant associations of humid places with a prevalence of Sphagnum and various helophytes. It is a syntaxon distributed with boreal distribution: the Caricion nigrae alliance affects the entire Italian peninsula; from the Alps it reaches Calabria where it presents itself with a couple of associations including the Sphagno inundati-Caricetea stellulate from Aspromonte. With the aforementioned association, the Sphagno auriculati-Caricetum echinatae, 
shares various species and among these the same Carex echinata $(=$ C. stellulata) which in Sicily takes on the role of territorial characteristic in the new association. Although it has also been represented, it remains exposed to serious risks of damage and further reduction, due to the proliferation of wild suidae and fallow deer, carelessly introduced into the territory of the Madonie protected natural area.

\section{Acknowledgments}

Work carried out with the support of PLANTA/Center for Research, Documentation and Training (Palermo, Italy). The authors are grateful to the professors Franco Pedrotti and Gianniantonio Domina for the critical reading of the article. A special thank to student Enrico Bajona (University of Palermo) for his preparation, by Google Earth Pro, of the Fig. 3 and for the graphics in Figs. 8-11. Finally, to Laura Bertini and Roberta Orlando for their precious collaboration within the PLANTA Center, in Palermo.

\section{References}

Aleffi, M., Tacchi, R. \& Poponessi, S., 2020: New Checklist of the Bryophytes of Italy. - Cryptog. Bryol. 41 (13): 147-195. https://doi.org/10.5252/cryptogamie-bryologie2020v41a13

Bartolucci, F., Peruzzi, L., Galasso, G., Albano, A., Alessandrini, A., Ardenghi, N. M. G., Astuti, G., Bacchetta, G., Ballelli, S., Banfi, E., Barberis, G., Bernardo, L., Bouvet, D., Bovio, M.,Cecchi, L., Di Pietro, R., Domina, G., Fascetti, S., Fenu, G., Festi, F., Foggi, B., Gallo, L., Gottschlich, G., Gubellini, L., Iamonico, D., Iberite, M., Jiménez-Mejías, P., Lattanzi, E., Marchetti, D., Martinetto, E., Masin, R. R., Medagli, P., Passalacqua, N. G., Peccenini, S., Pennesi, R., Pierini, B., Poldini, L., Prosser, F., Raimondo, F. M., Roma-Marzio, F., Rosati, L., Santangelo, A., Scoppola, A., Scortegagna, S., Selvaggi, A., Selvi, F., Soldano, A., Stinca, A., Wagensommer, R. P., Wilhalm, T. \& Conti, F. 2018: An updated checklist of the vascular flora native to Italy. - Pl. Biosyst. 52(2): 179-303. https://doi.org/10.1080/11263504.2017.1419996

Biondi, E., Blasi, C., Allegrezza, M., Anzellotti, I., Azzella, M. M., Carli, E., Casavecchia, S., Copiz, R., Del Vico, E., Facioni, L., Galdenzi, D., Gasparri, R., Lasen, C., Pesaresi, S., Poldini, L., Sburlino, G., Taffetani, F., Vagge, I., Zitti, S. \& Zivkovic, L. 2014: Plant communities of Italy: The Vegetation Prodrome. - P1. Biosyst. 148(4): 728-814. https://doi.org/ 10.1080/11263504.2014.948527

Brullo S., Scelsi, F. \& Spampinato, G. 2001: La vegetazione dell'Aspromonte. Studio fitosociologico. - Reggio Calabria.

Cambria, S. \& Raimondo, F. M.: Ilex aquifolium (Aquifoliaceae) and the relics of Tertiary forest vegetation with Colchic affinity in Sicily (C-Mediterranean). - Bocconea 29: 55-77. https://doi.org/10.7320/10.7320/Bocc29.055

Di Martino, A. \& Raimondo, F. M. 1976: Le infestanti delle colture di frumento della Sicilia occidentale. - Not. Fitosoc. 11: 45-74.

— \& - 1979: Biological and chorological survey of the Sicilian flora. - Webbia 34(1): 309-335. https://doi.org/10.1080/00837792.1979.10670174

- Marcenò C. \& Raimondo F. M., 1977: Sintesi degli studi condotti sulla vegetazione delle Madonie. - Giorn. Bot. Ital. 111 (6): 370-371.

Gamisans, J. 1977: La vegetation des montagnes corses. - Phytocoenologia 4 (1): 35-131. 
Marceno', C. \& Raimondo, F. M. 1977: Carex pallescens L. e C. paniculata L., rinvenute per la prima volta in Sicilia sulle Madonie. - Giorn. Bot. Ital. 111(6): 362-363.

Mucina, L., Bultmann, H., Diersen, K., Theurillat, J-P., Raus, T., Čarni, A, Šumberova, K., Willner, W., Dengler, J., Gavilan Garcia, R., Chytry, M., Hajek, M., Di Pietro, R., Iakushenko, D., Pallas, J., Daniels, F. J. A., Bergmeier, E., Santos Guerra, A., Ermakov, N., Valachovič, M., Schaminee, J. H. J., Lysenko, T., Didukh, Y. P., Pignatti, S, Rodwell, J. S., Capelo, J., Weber, H. E., Solomeshch, A., Dimopoulos, P., Aguiar, C., Hennekens, S. M. \& Ticyh, L. 2016: Vegetation of Europe: hierarchical floristic classification system of vascular plant, bryophyte, lichen, and algal communities. - Appl. Veg. Sci. 19 (Suppl. 1): 3-264. https://doi.org/10.1111/avsc.12257

Petronici, C., Mazzola, P. \& Raimondo, F. M. 1978: Nota introduttiva allo studio degli ambienti idromorfi delle Madonie. - Naturalista Sicil., s. 4, 2(1-2): 11-24.

Raimondo, F. M. 1975-76: La distruzione dell'ambiente sulle Madonie. Le Madonie (Castelbuono), n. 21, 22, 23, 24 (1975) e n. 1, 5, 6 (1976). Estratto pp. 30. Palermo.

- 1984: On the natural history of the Madonie Mountains. - Webbia 38(1): 29-52.

- 1979: x Carex boenninghausiana Weihe in Sicilia: prima segnalazione per la flora italiana. Naturalista Sicil., s. 4, 3(1-2): 53-59.

— \& Dia, M. G. 1978: Note Briogeografiche. I. Il genere Sphagnum L. in Sicilia. - Naturalista Sicil., s. 4, 2(3-4): 109-126.

— \& Mazzola, P. 1983: Aggiunte alla flora delle Madonie. - Atti Accad. Sci. Palermo, s. 4, 40(1). Estratto pp.11.

— \& Ottonello, D. 1981: Entita' nuove per la flora siciliana. - Atti Accad. Sci. Palermo, s. 4, 38(1): 143-152.

— \& Romano, S. 1984: Excursion a Portella Mandarini et Geraci (9 juin 1983). - Webbia 38(1): $67-$ 68.

— \& Spadaro, V. 2002: New record of Carex stellulata (Cyperaceae) in Sicily. - Fl. Medit. 12: 2932.

-, Scialabba, A. \& Dia, M. G. 1980: Note Briogeografiche. III. Distribuzione in Italia di Aulacomnium palustre (Hedw.) Schwaegr. ed ecologia della specie nelle stazioni siciliane.Naturalista Sicil., s. 4, 4(3-4): 79-99.

-, Mazzola, P. \& Rossitto, M. 1981: Note briogeografiche. IV. Distribuzione ed ecologia di Polytrichum commune L. ex Hedw. in Sicilia. - Atti Accad. Sci. Palermo 40(1). Estratto pp.15. 
294 Raimondo \& al.: The class Scheuchzerio-Caricetea nigrae in Sicily: a new association...

\section{ANNEXES}

Annex 1. - List of the syntaxa cited in the texte and Table 1.

Caricetalia nigrae Koch 1926

Caricion nigrae Koch 1926 em. Klika 1934

Cynosurion cristati Tüxen 1947

Geranium versicoloris-Fagion sylvaticae Gentile 1970

Parvocaricetea Westhoff in Westhoff \& Den Held 1969

Quercetalia pubescenti-petraeae Klika 1933

Quercion pubescenti-petraeae Br.-Bl. 1932

Quercetalia ilicis Br.-Bl. 1936

Quercion ilicis Br.-Bl. ex Mol. 1934 em. Riv.-Mart. 1975

Scheuchzerio palustris-Caricetea nigrae Steiner 1992

Scheuchzerio-Caricetea fuscae Tüxen 1937

Sphagno auriculati-Caricetum echinatae Raimondo \& Di Gristina ass. nov. hoc loco

Sphagno inundati-Caricetum stellulatae Brullo, Scelsi \& Spampinato 2001

\section{Annex 2 - Alphabetical list of specific and subspecific taxa named in Table 1.}

\section{VASCULAR PLANTS}

Athyrium filix-foemina (L.) Roth

Bellis perennis subsp. hybrida (Ten.) Nyman

Carex demissa Hornem.

Carex distans $\mathrm{L}$.

Carex echinata Murray

Carex paniculata L.

Carex punctata Gaudin

Dactylorhiza maculata subsp. saccifera (Brongn.) Diklić

Deschampsia cespitosa (L.) P. Beauv.

Eupatorium cannabinum L.

Festuca circummediterranea Patzke

Galium palustre subsp. elongatum (C. Presl) Arcang.

Holcus lanatus L.

Hypericum tetrapterum Fr.

Isolepis setacea (L.) R. Br.

Juncus conglomertus L.

Juncus fontanesii J. Gay

Lycopus europaeus L.

Lysimachia nemorum L.

Mentha aquatica L.

Mentha pulegium L.

Osmunda regalis $\mathrm{L}$.

Poa trivialis L. 
Potentilla reptans $\mathrm{L}$.

Pteridium aquilinum (L.) Kuhn

Pulicaria dysenterica (L.) Bernh.

Ranunculus fontanus C. Presl

Rubus sp.

Salix pedicellata Desf.

Samolus valerandi $\mathrm{L}$.

Solenopsis bivonae (Tineo) M.B. Crespo, Serra \& Juan

Struthiopteris spicant (L.) Weiss

Teucrium scordium L.

Trifolium repens $\mathrm{L}$.

Veronica anagallis-aquatica L.

Veronica beccabunga L.

\section{BRYOPHYTES}

Aulacomnium palustre (Hedw.) Schwaegr.

Calliergonella cuspidate (Hedw.) Loeske

Calypogeia sp.

Mnium sp.

Polytrichum commune Hedw.

Sphagnum auriculatum Schimp.

Addresses of the authors:

Francesco Maria Raimondo ${ }^{1}$, Dali Varshanidze ${ }^{2}$, Emilio Di Gristina ${ }^{3}$,

${ }^{1}$ PLANTA/Center for Research, Documentation and Training, Via Serraglio Vecchio 28, 90123 Palermo, Italy. E-mail: raimondo@centroplantapalermo.org

${ }^{2}$ Batumi Botanical Garden, Green Cape, Batumi, 6411, Georgia. E-mail: dvarshanidze@bbg.ge

${ }^{3}$ Department of Agricultural, Food and Forest Sciences (SAAF), University of Palermo, Viale delle Scienze, bld. 4, 90128 Palermo, Italy. E-mail: emilio.digristina@unipa.it 
